\title{
Isolation and characterization of sporulation lac $Z$ fusion mutants of Bacillus megaterium
}

\author{
Yi-Ping TAO and Patricia S. VARY* \\ Department of Biological Sciences, Northern Illinois University, DeKalb, IL 60115, USA
}

(Received 2 July 1990; revised 9 November 1990; accepted 12 December 1990)

\begin{abstract}
A derivative of Bacillus megaterium QM B1551 cured of all seven resident plasmids was mutated to Lac $^{-}$. Transposon Tn 917 carrying $l a c Z$ and $c a t$ was then used to isolate four spo: : lac Z-cat fusion mutants by screening for colonies expressing the fusion in stationary phase. The sporulation frequencies of the mutants ranged from $10^{-7}$ to $10^{-2}$. Macrolide, lincosamide and streptogramin B resistance (MLS ${ }^{r}$ ) of the mutants cotransduced $100 \%$ with the sporulation defect and all four mutations mapped near trp by transduction in the order: trp-his $H$-spo. All four mutants isolated were defective early in sporulation since $\beta$-galactosidase could be detected between zero and $\mathbf{2} \mathrm{h}$ after the end of exponential growth. Electron microscopy of two of the mutants expressing the enzyme at $t_{1}-t_{2}$ revealed a defect prior to or just at the beginning of septum formation in one, and after completion of septum formation in the other. Little or no synthesis of dipicolinic acid, glucose dehydrogenase or alkaline phosphatase was detected in the mutants, but each was neutral protease positive. These results show that the mutations were in at least two early genes expressed before glucose dehydrogenase production. This study represents the first genetic characterization of sporulation mutants in B. megaterium and also demonstrates that gene fusion technology can be used in this species.
\end{abstract}

\section{Introduction}

Sporulation in Bacillus is a complex cell differentiation event involving over 50 operons (Losick et al., 1986; Piggot \& Hoch, 1985). The genes that are specifically required for endospore formation are called spo genes and, when mutated, arrest development at one of six morphologically defined stages (stage 0 , II, III, etc.) without significantly affecting the vegetative phase of growth. The genes are designated as spo0, spoII, spoIII, etc. Several laboratories have used the presence or absence of sporulation-specific enzymes and compounds synthesized at defined stages in sporulation to help identify the stages at which those mutants are blocked (Losick et al., 1986; Sandman et al., 1987). The sporulation genes have been studied most extensively in Bacillus subtilis and many of them have been cloned (see review by Mandelstam \& Errington, 1987).

Because Bacillus megaterium sporulates more efficiently than most Bacillus spp. (Millet \& Aubert, 1969), it has been the species of choice among biochemists for the biochemical characterization of the sporulation process. For example, the spore has been examined for its

Abbreviation: DPA, dipicolinic acid. protein- synthesizing systems (Deutscher et al., 1968), for several electron-transport enzymes (Crafts-Lighty \& Ellar, 1980; Wilkinson \& Ellar, 1975) and for its membrane characteristics by electron spin resonance (Janoff et al., 1979). Sporulating cells have been tested for several enzymes (Chatelain, 1975), fatty acids (Scandella \& Kornberg, 1969), polyamines (Setlow, 1974), proteases (Chaloupka et al., 1982; Setlow, 1975), electron transport (Wilkinson \& Ellar, 1975), calcium accumulation (Bronner \& Freund, 1972; Hogarth \& Ellar, 1978), dipicolinic acid (DPA) (Bach \& Gilvarg, 1966), coat protein synthesis (Imagawa et al., 1985) and penicillin-binding proteins (Todd \& Ellar, 1982). Several small acid-soluble proteins (SASPs) and their specific protease have also been isolated, cloned and characterized by Setlow and co-workers. These SASPs have been shown to interact with DNA and to provide an important source of amino acids during germination and outgrowth (Fliss et al., 1985; Fliss \& Setlow, 1985). However, it has been difficult to progress very far in the analysis of sporulation in B. megaterium without methods of genetic exchange.

In the last few years, our laboratory has developed genetic systems for $B$. megaterium and has mapped over 45 genes into linkage groups covering approximately 
Table 1. B. megaterium strains used in this study

\begin{tabular}{|c|c|c|}
\hline Strain & Genotype* & $\begin{array}{l}\text { Source or } \\
\text { reference }\end{array}$ \\
\hline QM B1551 & Wild-type & J.C. Vary $\dagger$ \\
\hline PV3 & hisH2I & Callahan et al. (1983) \\
\hline PV195 & $\operatorname{trpB} 3$ phe $A 2$ & This study \\
\hline PV415 & $\mathrm{p}^{-7} / a c-3$ & This study \\
\hline PV447 & $\mathrm{p}^{-7}$ lac -3 lac-6 & This study \\
\hline PV469 & $\mathrm{p}^{-7}$ lac-3 lac-6/pTV53 tet Tn917-lacZ-cat & This study \\
\hline PV497 & $\mathrm{p}^{-7}$ lac-3 lac-6 spo-54::Tn917-lacZ-cat & This study \\
\hline PV503 & spo-54: : Tn917-lacZ-cat & This study \\
\hline JV59 & $\operatorname{trpE4}$ & J. C. Vary \\
\hline JV62 & $\operatorname{trpE} 7 \mathrm{rps} L 3$ & J. C. Vary \\
\hline JV 109 & $r i b-2$ & J. C. Vary \\
\hline PV517 & spo-56: : Tn917-lacZ-cat & This study \\
\hline PV518 & spo-57: :Tn917-lacZ-cat & This study \\
\hline PV519 & spo-58::Tn917-lacZ-cat & This study \\
\hline
\end{tabular}

* Genotype abbreviations: cat, chloramphenicol resistance; $\operatorname{Tn} 917$, transposon $\operatorname{Tn} 917$; $\mathbf{M L S}^{r}$, resistant to macrolides, lincosamides and streptogramin $\mathbf{B} ; \mathrm{p}^{-7}$, cured of all seven resident plasmids; tet, tetracycline resistance; lac $Z$, promoterless gene of $\beta$-galactosidase; $l a c$, lactose; spo, sporulation.

$\dagger$ J. C. Vary, University of Illinois School of Medicine at Chicago.

$70 \%$ of the chromosome (English \& Vary, 1986; Sussman et al., 1988; Vary, 1979; Vary \& Tao, 1988; S. L. Palm \& P. S. Vary, unpublished). Although the sporulation process has been studied extensively in this species (Chatelain, 1975; Ellar et al., 1967, 1975; Ellar \& Posgate, 1974; Greene et al., 1971), only a few spo mutants have been reported. Several DPA mutants that could not sporulate were analysed for their accumulation of calcium by Ota (1980), and spo mutants were analysed for nutritional defects by Chatelain \& Fargette (1976) and Kretschmer \& Fielder (1974). Coatless mutants have been isolated by Koshikawa et al. (1984) and Imagawa et al. (1985). We have also previously reported the isolation of several sporulation-defective mutants by insertional inactivation (Bohall \& Vary, 1986), but to our knowledge, no sporulation mutants have been genetically characterized in this species.

In $B$. subtilis, a genetic tool that has greatly facilitated the genetic analysis of sporulation has been the transposon Tn 917 originally derived from Streptococcus faecalis (Tomich et al., 1980). This transposon has been modified by Youngman and coworkers in a series of constructions to generate derivatives that can be used for insertion mutagenesis, for constructing gene fusions to $l a c Z$ and/or cat (chloramphenicol acetyltransferase), and for cloning (Youngman et al., 1985a, b, 1989). Sandman et al. (1987) have demonstrated the usefulness of $\operatorname{Tn} 917$ in studying sporulation by isolating and characterizing 21 new spo mutations in $B$. subtilis, among which nine represented new loci. Bohall \& Vary (1986) introduced $\operatorname{Tn} 917$ into $B$. megaterium and found that it transposed randomly without hotspots. Of the mutants isolated, approximately
$1 \%$ were spo mutants. The use of transposition should now facilitate progress toward isolating and characterizing sporulation mutants in $B$. megaterium. This paper reports the construction of a $\mathrm{Lac}^{-}$strain and the use of lac $Z$ fusion technology to isolate and characterize four spo: :lacZ-cat fusion mutants.

\section{Methods}

Strains, plasmids and media. All B. megaterium strains were derived from strain QM B1551 (ATCC 12872) and are listed in Table 1. B. subtilis mutants IS9 (trpC2 pheAl spo0A12), IS65 (metC3 tal-1 spoIVF88) and IS66 (metC3 rpo-B2 spoVC285) were obtained from the Bacillus Genetic Stock Center, Ohio State University, USA. Strain PY332 (trpC2 thrA5), carrying pTV53, was kindly provided by Dr Philip Youngman (Department of Microbiology, University of Pennsylvania School of Medicine, USA). Plasmid pTV53 carries resistance to tetracycline $\left(\mathrm{Tc}^{\mathrm{r}}\right)$ and is temperature sensitive for replication (Youngman et al., 1985a). It also carries transposon Tn917 into which promoterless tandem lac $Z$ and $c a t$ genes, preceded by a Bacillus ribosome-binding site, have been inserted without interference with transposition or resistance to macrolides, lincosamides and streptogramin B (MLS') (Youngman et al., 1985a). Luria-Bertani (LB) medium (Levine, 1957) was used in transposition experiments, and SNB medium (English \& Vary, 1986) was used for routine growth, sporulation, and preparation of phage lysates. Antibiotic concentrations were $10 \mu \mathrm{g}$ tetracycline $(\mathrm{Tc}) \mathrm{ml}^{-1}, 0 \cdot 15 \mu \mathrm{g}$ erythromycin $(\mathrm{Em})$ $\mathrm{ml}^{-1}$ for induction, $5 \mu \mathrm{g}$ erythromycin $\mathrm{ml}^{-1}$ and $250 \mu \mathrm{g}$ lincomycin (MLS) $\mathrm{ml}^{-1}$ for transposon selection, and $3.5 \mu \mathrm{g}$ chloramphenicol $(\mathrm{Cm})$ $\mathrm{ml}^{-1}$ for selection of fusions. Cultures were grown at $30^{\circ} \mathrm{C}$ with shaking unless otherwise indicated.

Plasmid isolation, transformation, transduction and mutagenesis. Plasmid DNA was isolated by the method of Kawamura et al. (1985). For transformations, the PEG-mediated protoplast method of Von 
Tersch \& Carlton (1983) was used except that cells were first regenerated overnight on nonselective RHAF plates, then replicated to SNB plates containing the selective antibiotic(s). After $12-24 \mathrm{~h}$ further incubation, transformants could be observed. Media, procedures for preparing lysates, and transductions with phage MP13 have been described previously (English \& Vary, 1986) except that $6 \mathrm{~g}$ $\mathrm{KH}_{2} \mathrm{PO}_{4} \mathrm{1}^{-1}$ was also added to the minimal glucose medium. Transductants appearing on minimal plates were picked to minimal medium with inducing Em. After $24-48 \mathrm{~h}$ incubation, colonies were replica plated to minimal medium and LB-MLS medium to determine cotransduction frequency. Mutagenesis by nitrosoguanidine and by UV irradiation have been described previously (English \& Vary, 1986).

Selection of transposon insertions. To isolate transposition mutants, a plate method using a single incubation at $47^{\circ} \mathrm{C}$ was used as follows. Strain PV469 carrying pTV53 was streaked on an LB-Tc-Em plate and was incubated overnight. A loopful of the culture was inoculated into 3 $\mathrm{ml}$ LB-MLS-Tc broth with aeration. When the $\mathrm{OD}_{660}$ reached $0 \cdot 5-0 \cdot 6$, cells were diluted and spread onto LB-MLS plates and incubated at $30^{\circ} \mathrm{C}$ and $47^{\circ} \mathrm{C}$ so that transposition frequencies could be calculated as previously described (Bohall \& Vary, 1986). After $36-48 \mathrm{~h}$ incubation, the $47^{\circ} \mathrm{C}$ plates were replica plated to SNB-MLS plates containing $60 \mu \mathrm{g} \mathrm{X}-\mathrm{Gal} \mathrm{ml}^{-1}$, and were allowed to sporulate for $3 \mathrm{~d}$ at $30^{\circ} \mathrm{C}$. Deepblue colonies were picked to SNB-MLS plates, incubated overnight, then replica plated to fresh SNB-MLS plates. After 8-12 h incubation, colonies were replicated to SNB-MLS plates plus or minus $\mathrm{Cm}$ to test $\mathrm{Cm}$ sensitivity $\left(\mathrm{Cm}^{\mathrm{s}}\right)$, and to SNB-MLS-Tc plates to test for plasmid curing $\left(\mathrm{Tc}^{\mathrm{s}}\right)$. The $\mathrm{Cm}^{\mathrm{s}} \mathrm{Tc}^{\mathrm{s}}$ colonies were purified, incubated for $3 \mathrm{~d}$ and examined microscopically for absence of refractive spores. Sporulation frequencies were tested by growing cultures with shaking at $30^{\circ} \mathrm{C}$ for $24 \mathrm{~h}$, diluting and plating both heated $\left(80^{\circ} \mathrm{C}, 10 \mathrm{~min}\right)$ and unheated cultures and calculating no. of viable colonies (heated)/no. of viable colonies (unheated) relative to the wild-type control.

Electron microscopy. Cultures were incubated with shaking for $24 \mathrm{~h}$ and harvested. The method of Hirsch \& Fedorko (1968) was used to simultaneously fix the cells in $2.5 \%(\mathrm{v} / \mathrm{v})$ glutaraldehyde and $2 \%(\mathrm{w} / \mathrm{v})$ osmium tetroxide and to embed them in a Mollenhauer-Epon Araldite Resin mixture. The cells were sectioned with a Sorval 'Porter Blum' ultramicrotome, stained with $2 \%(\mathrm{w} / \mathrm{v})$ uranyl acetate and counterstained with $0 \cdot 2 \%(\mathrm{w} / \mathrm{v})$ lead citrate. The preparations were viewed with an Hitachi HS-9 transmission electron microscope operated at $75 \mathrm{kV}$.

Enzyme and antibiotic assays. Cells were prepared and assayed for $\beta$ galactosidase by the method of Miller (1972) as modified by Errington \& Mandelstam (1986) except that the cell pellet was resuspended in $0.8 \mathrm{ml} \mathrm{Z}$ buffer instead of $1 \mathrm{ml}$. Dipicolinic acid (DPA) was assayed as described by Janssen et al. (1958) and modified by Rotman \& Fields (1968). Protease was assayed on SNB plates containing $1 \%(w / v)$ skim milk. Following cell growth in SNB plus 5 mM-potassium phosphate ( $\mathrm{pH} 7 \cdot 0$ ), to inhibit possible vegetative alkaline phosphatase, alkaline phosphatase was assayed by the method of Hulett \& Jensen (1988). One unit of alkaline phosphatase was defined as the amount of enzyme necessary to hydrolyse $1 \mathrm{nmol} p$-nitrophenyl phosphate $\min ^{-1}$. The specific activity was expressed as units per $\mathrm{OD}_{660}$ unit. Glucose dehydrogenase was assayed during growth and stationary phase by the method of Sadoff et al. (1965) except that NADH was used as a standard. One unit of enzyme was defined as the amount necessary to convert $1 \mathrm{nmol}$ substrate $\min ^{-1}$. The cells were collected at various times, spun down, quick-frozen in dry ice/ethanol, and stored at $-70{ }^{\circ} \mathrm{C}$ until assayed. The enzyme was released by sonicating cells using the method of Hill (1983) except that $40 \mathrm{ml}$ sample was used and sonication was applied 15 times ( $30 \mathrm{~s}$ each time) at $38 \mathrm{~W}$ with a microtip probe on a Vibra Cell ' $\mathrm{VC}$ 250' ultrasonic processor. Antibiotic production in $B$. megaterium was assayed by the method of
Sandman et al. (1987) using $B$. subtilis spo0A and three of the $B$. megaterium early spo mutants as sensitive overlay strains.

\section{Results}

\section{Isolation of a Lac- strain and transformation of pTV53}

Strain QM B1551 has been cured of all seven plasmids to yield strain PV361 (Vary \& Tao, 1988). To isolate a $\mathrm{Lac}^{-}$ derivative, PV361 was then mutagenized by nitrosoguanidine and five colonies were found that could not grow on minimal lactose, yet were still blue on X-Gal. One of these colonies, PV415, was then spread on X-Gal plates, exposed to UV light and screened for white colonies. Out of several hundred colonies screened, four white colonies were isolated and purified. One of them was designated as PV447. Plasmid pTV53, isolated from $B$. subtilis PY332, was then used to transform $B$. megaterium PV447 protoplasts with selection for tetracycline resistance. A pTV53-containing transformant was purified and designated as PV469. The presence of the plasmid was verified by erythromycin induction, selection for MLSr and visualization of the plasmid by agarose gel electrophoresis (data not shown).

\section{Isolation of insertion spo mutants}

Transposition experiments were done using PV469 as described in Methods. The average transposition frequency was $8.9 \times 10^{-4}$. In Tn917-lacZ-cat, a promoterless $l a c Z$ gene and a promoterless $c a t$ gene are arranged as a tandem pair without a transcriptional terminator between them. Thus, insertions that activate the transposon-borne lacZ-cat genes late in cell growth would give blue colonies on X-Gal plates, but would be $\mathrm{Cm}^{\text {s }}$ during exponential growth (Youngman et al., 1985a). In each transposition experiment when deep-blue colonies were picked, about $80 \%$ were found to be cured of the plasmid $\left(\mathrm{Tc}^{\mathrm{s}}\right)$. These colonies were tested for $\mathrm{Cm}^{\mathrm{s}}$ during exponential growth, then were screened by phase microscopy for inability to sporulate. The spo mutants represented about $15 \%$ of the deep-blue $\mathrm{Cm}^{\mathrm{s}}$ colonies.

Mutants spo-56: : Tn917-lacZ-cat and spo-57: :Tn917lacZ-cat were from the same transposition experiment, but were retained because of differences in expression of $\beta$-galactosidase. The sporulation frequency of spo$54:: \operatorname{Tn} 917-l a c Z$-cat was $5 \times 10^{-6}$ in the $\mathrm{Lac}^{-}$strain, but was $1 \times 10^{-3}$ in the wild-type strain. The frequencies of sporulation (after transfer to the wild-type strain) for spo56:: Tn917-lacZ-cat, spo-57::Tn917-lacZ-cat and spo58::Tn917-lacZ-cat were $1 \times 10^{-2}, 6 \times 10^{-7}$ and $8 \times 10^{-7}$, respectively. 

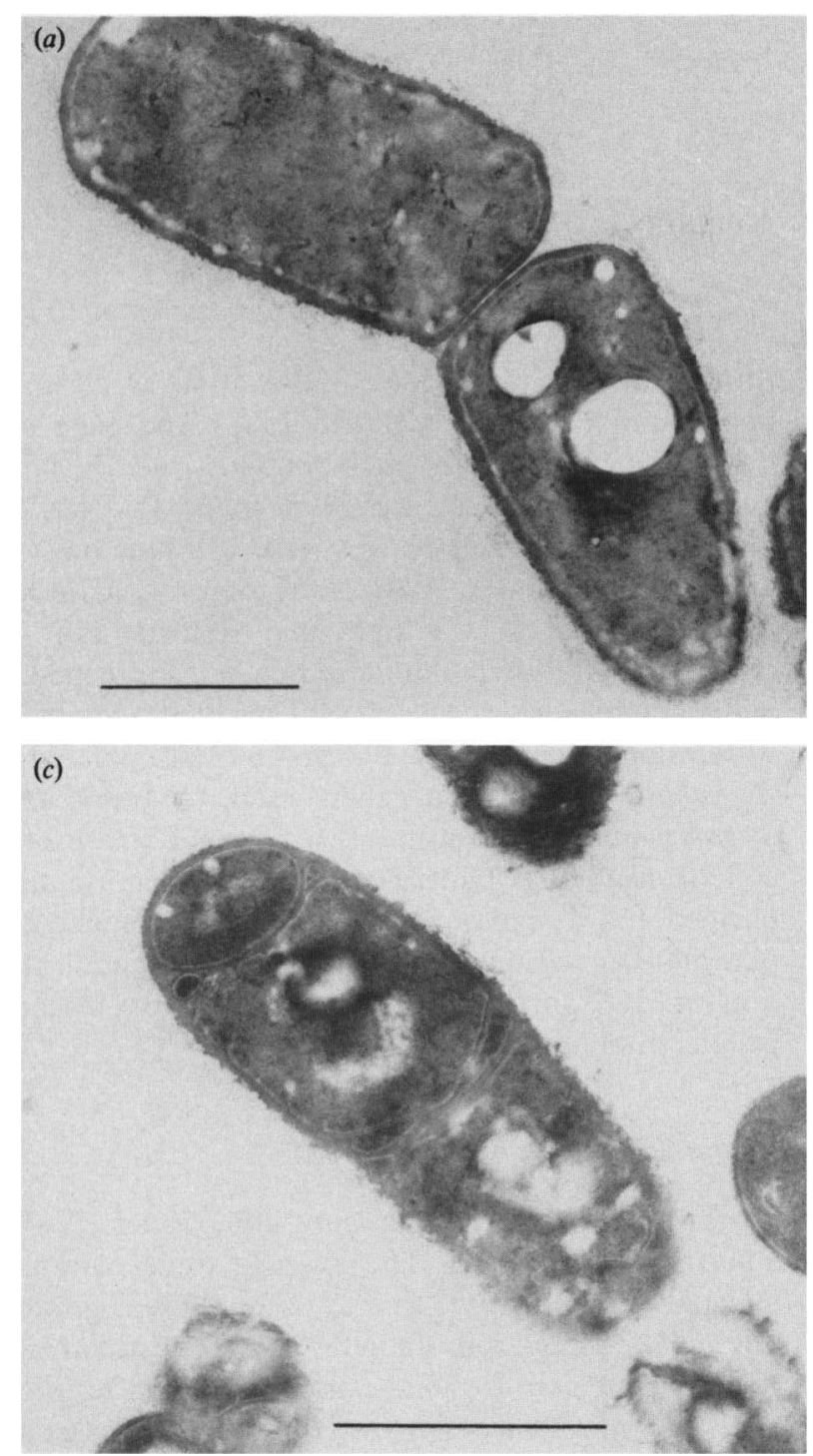

Transduction of the spo fusion mutants.

During preliminary tests, it was shown that the $\mathrm{Lac}^{-}$ strain PV447 sporulated more slowly than the wild-type (data not shown), so that the timed expression of a sporulation gene could not be precisely studied in this background. Therefore, all four mutations were transduced into wild-type QM B1551 selecting for MLS ${ }^{r}$ to generate isogenic strains. Phage and cells were plated on SNB with inducing Em and incubated overnight. The confluent growth was replica plated to SNB-MLS plates. Colonies appeared after $48 \mathrm{~h}$ only on the test plates, not on controls to which no phage was added. Transductants grew on minimal medium without glucose and sodium citrate, but with $0 \cdot 2 \%$ lactate and $25 \mathrm{~mm}$-glutamate, and so were not TCA cycle mutants (Szulmajster \& Hanson, 1965). Cotransduction of each of the spo mutations with MLS $^{r}$ was $100 \%$.

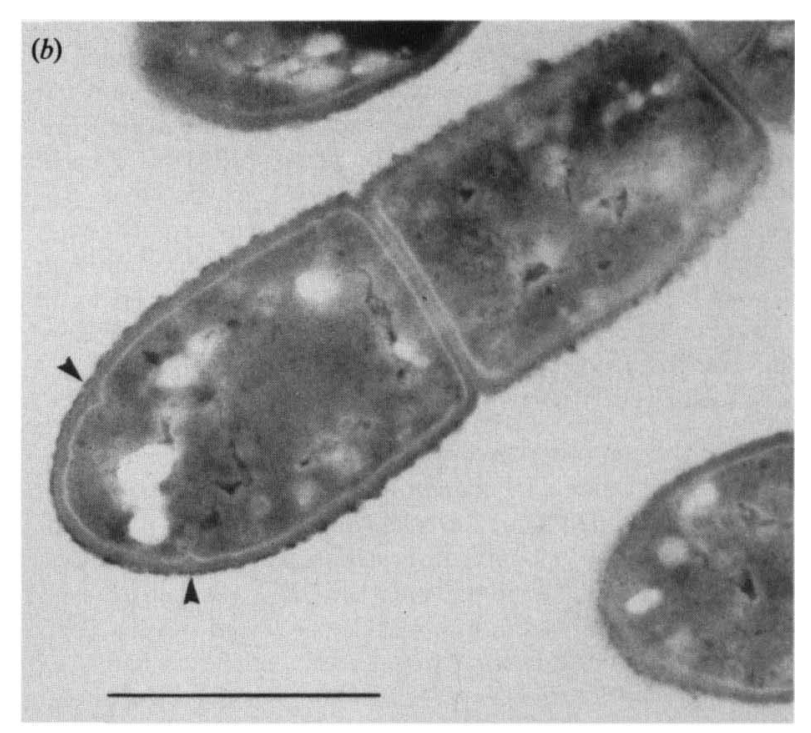

Fig. 1. Electron micrographs of PV503 and PV519. (a) PV503 showing most cells blocked before septum formation; (b) PV503 with early aborted septa (arrows) occurring in about $1 \%$ of the cells. (c) PV519 showing block at stage II at completion of septum formation and presence of aberrant septa. Bars, $1 \mu \mathrm{m}$.

\section{Electron microscopy}

When the mutant containing spo-54::Tn917-lacZ-cat (PV503) was viewed by electron microscopy, it was found to be blocked at the onset of septum formation (see Fig. $1 \mathrm{a})$. Rare cells $(<1 \%)$ were observed that had slight indentations of septa (Fig. $1 b$ ). Mutant spo-58: :Tn917lacZ-cat (PV519), in contrast, was able to complete septum formation, although some aberrant septa were also observed (see Fig. $1 \mathrm{c}$ ). It is now designated as a late spoll mutant.

\section{$\beta$-Galactosidase and DPA production}

Since transcription of the promoterless lac $Z$ gene on Tn917 should be under the control of the spo promoters, spo gene expression could be monitored by the assay of $\beta$ galactosidase activity. To determine when a spo gene was 


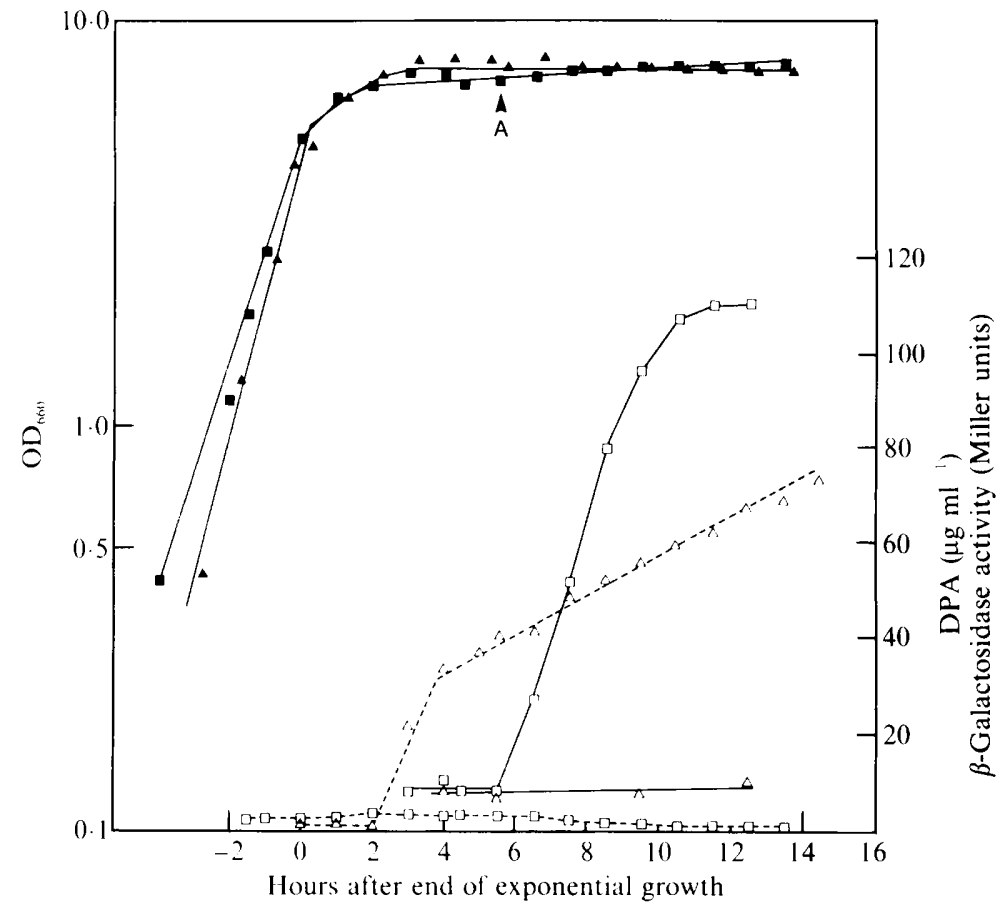

Fig. 2. Measurement of $\beta$-galactosidase activity and DPA of wild-type and PV503. Filled symbols represent the $\mathrm{OD}_{660}$ of QM B1551 ( $\left.\mathbf{\square}\right)$ and PV503 ( $\boldsymbol{\Delta}$ ). Open symbols represent the levels of DPA in QM B1551 ( $\square$ ) and PV503 $(\triangle)$. Dashed lines represent the $\beta$-galactosidase activities of QM B1551 ( $\square---\square)$ and of PV503 minus that of QM B1551 ( $\triangle--\triangle)$. The time when intracellular refractile spores of $\mathrm{QM}$ B1551 are first observed $(<1 \%)$ is shown at A expressed in relation to DPA synthesis and appearance of refractile spores, spo-54::Tn917-lacZ-cat and QM B1551 were grown in SNB as shown in Fig. 2. Deviation from exponential growth was designated as $t_{0}$. It can be seen that, although QM B1551 grows on minimal-lactose plates and is blue on X-Gal plates, it expressed only about 5 units of $\beta$-galactosidase activity. The net enzyme activity of the spo fusion mutant began to increase at $t_{1.5}-t_{2}$. The production of DPA could be detected in the wild-type at $t_{5.5}-t_{6}$, when less than $1 \%$ intracellar refractile forespores were observed. DPA synthesis in the fusion mutant could not be detected. The time of expression of $\beta$-galactosidase in all four mutants is shown in Fig. 3.

\section{Enzyme assays}

Synthesis of several enzymes such as alkaline phosphatase and glucose dehydrogenase begins during specific stages of sporulation in B. subtilis (Waites et al., 1970) and their synthesis has been used to help delineate mutants blocked at specific stages (Mandelstam \& Errington, 1987; Sandman et al., 1987). Expression of these enzymes was tested in wild-type B. megaterium and compared to one of the mutants as shown in Fig. 4. Alkaline phosphatase was detectable in the wild-type at $t_{3}-t_{4} ;$ glucose dehydrogenase at $t_{4}$. Mutant spo-54 produced little or no alkaline phosphatase (Fig. $4 b$ ) and only $19 \%$ of the glucose dehydrogenase of wild-type (Fig.

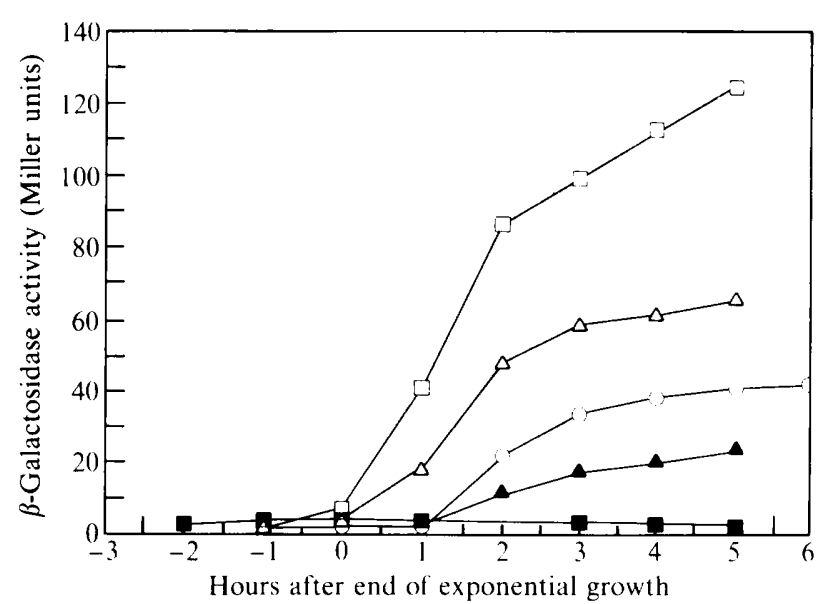

Fig. 3. Comparison of expression of $\beta$-galactosidase in all four spo: :Tn917-lacZ-cat mutants. $\square$, QM B1551; O, spo-54; $\triangle$, spo-56; A, spo-57; $\square$, spo-58.

$4 a$ ). The data in Table 2 show that none of the four mutants produced significant amounts of either enzyme.

Assays for antibiotic and protease production and motility

Mutations in most spo0 genes in $B$. subtilis also prevent motility and production of extracellular proteases and antibiotics (Losick et al., 1986; Sandman et al., 1987). These effects were also tested in B. megaterium wild-type and the early sporulation mutants. Antibiotic production 

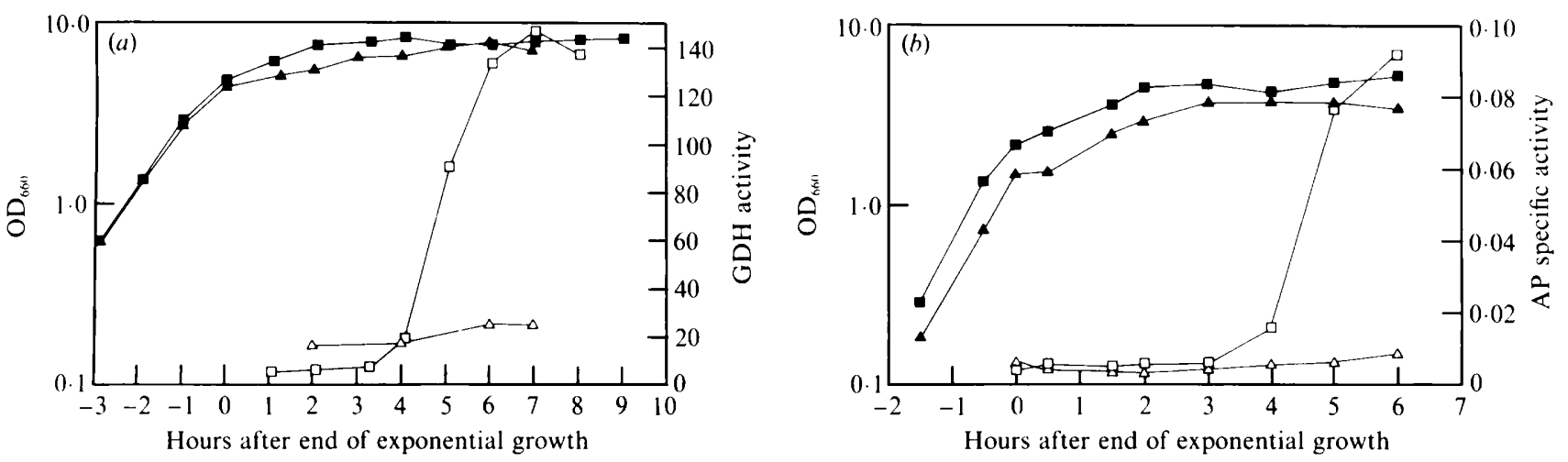

Fig. 4. Production of alkaline phosphatase (AP) and glucose dehydrogenase (GDH) in the wild-type and in fusion mutant PV503. Filled symbols in $(a)$ and $(b)$ represent the $\mathrm{OD}_{660}$ of QM B1551 ( $\left.\mathbf{a}\right)$ and PV503 $(\boldsymbol{\Lambda})$. Open symbols represent production of glucose dehydrogenase $(a)$ and alkaline phosphatase $(b)$ by QM B1551 ( $\square)$ and PV503 $(\triangle)$ (see Methods for details).

Table 2. Assay of glucose dehydrogenase at $t_{6}$, alkaline phosphatase at $t_{5}$ and DPA after $24 \mathrm{~h}$ incubation, of wild-type and mutants

\begin{tabular}{lrrr}
\hline \hline \multicolumn{1}{c}{ Strain } & GDH* & AP† & DPA \\
\hline QM B1551 & 17.26 & 3.51 & 120.9 \\
PV503 (spo-54) & 3.31 & 0.30 & 11.4 \\
PV517 (spo-56) & 2.34 & 0.28 & 9.0 \\
PV518 (spo-57) & $1 \cdot 16$ & 0.16 & 7.9 \\
PV519 (spo-58) & 1.68 & 0.13 & 10.4 \\
\hline \hline
\end{tabular}

* Glucose dehydrogenase, $\mathrm{nmol} \mathrm{min}^{-1}$.

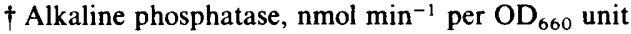
$\ddagger$ Dipicolinic acid, $\mu \mathrm{g}$ (ml culture) $)^{-1}$.

was tested by overlaying an antibiotic-sensitive $B$. subtilis spo0A strain onto B. megaterium wild-type, PV503, and positive controls of $B$. subtilis spoIVF and spoVC. Only the late spo mutants of $B$. subtilis inhibited spoOA growth (data not shown). Since $B$. megaterium might produce an antibiotic not active on the $B$. subtilis spoO $A$ mutant, all four mutants which expressed $\beta$-galactosidase very early were used as the sensitive overlay strains over $B$. megaterium wild-type and $B$. subtilis spo0A, spoIVF and spoVC strains. Again, the B. megaterium mutants were inhibited only by the $B$. subtilis spoIVF and spoVC strains.

When the wild-type strain and the fusion mutants were tested for protease production, all were found to be positive. The extracellular protease of QM B1551 is completely inhibited by EDTA (data not shown) and therefore is probably the single neutral, or metalloprotease reported for other strains of $B$. megaterium (Chaloupka et al., 1982; Millet \& Aubert, 1969; Priest, 1977). Indeed, we have isolated a mutant that produces no detectable extracellular proteases on milk plates (D. A. Lach \& P. S. Vary, unpublished data). When the supernatants of cultures of wild-type and spo mutants produced at different stages of growth were dropped on SNB $+1 \%$ skim milk plates, a zone of clearing was seen from $t_{1}$ to $t_{6}$ in both wild-type and fusion mutants.

Motility was measured by stabbing wild-type and PV503 into SNB containing $0.25 \%$ agar, and also by microscopic observation. There was only weak motility in all strains tested, with no evident differences.

\section{Mapping of the insertional mutations}

Since a transposon insertion gives the mutated gene an easily selectable marker, it was possible to map the spo loci by screening for MLSr cotransductants. A mapping strain kit of 12 strains was used to test for cotransduction (Vary \& Tao, 1988). As shown in Table 3 and Fig. 5, all four of the mutant loci could be mapped in the trp-his region of the chromosome. As none were linked to rib, they probably lie on the rib-distal side of his $H$. All four mutant loci have also been detected on the same $339 \mathrm{~kb}$ NotI fragment as trp and his $H$ by using pulse gel electrophoresis and probing Not $\mathrm{I}$ digests of mutants and wild-type with an internal fragment of $\mathrm{Tn} 917$ (W. B. Muse \& P. S. Vary, unpublished data).

\section{Discussion}

In this study, we report the first isolation and characterization of spo::lac $Z$ fusion mutants in $B$. megaterium using the Tn917-lacZ-cat transposon. Tn917-lacZ-cat transposed efficiently and randomly at a slightly higher frequency than the unmodified transposon. The extent of curing of the plasmid by elevated temperature could also be monitored as in B. subtilis (Youngman et al., 1985a) by the intensity of the blue colour of colonies on X-Gal 


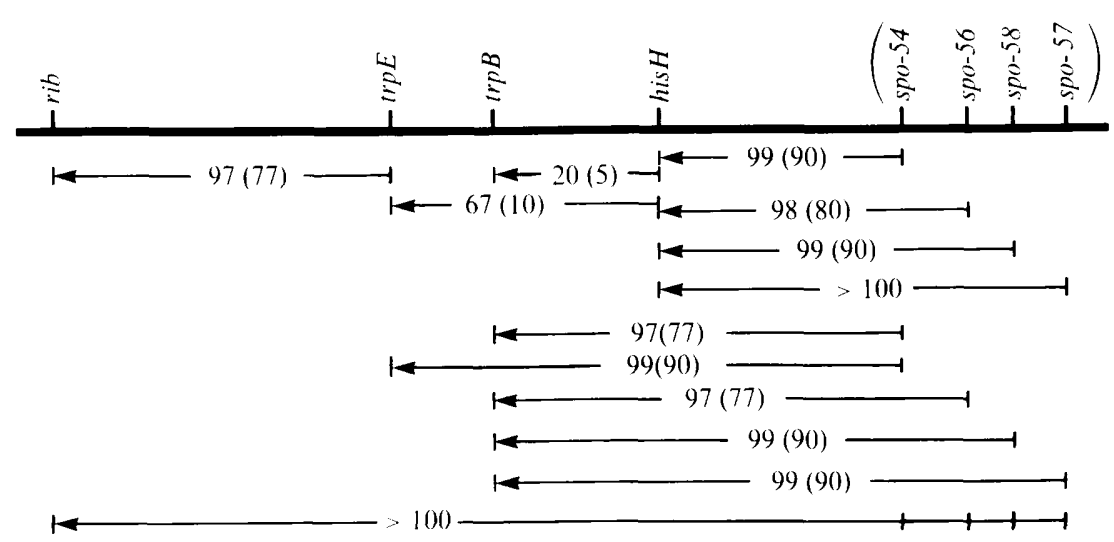

Fig. 5. The genetic linkages of the spo mutations with various loci. Linkages are expressed as $100 \%$ minus the percentage cotransduction. The hisH trp cotransduction data are from Callahan $e t$ al. (1983). Numbers in parentheses are values obtained by the formula of Kemper (1974) and correlate more closely to actual physical distances.

Table 3. Mapping of spo: : Tn917-lacZ-cat mutations

\begin{tabular}{|c|c|c|c|}
\hline Donor & Recipient & Cotransduction* & $\begin{array}{c}\text { Cotransduction } \\
\text { frequency } \\
(\%)\end{array}$ \\
\hline PV497 (spo-54) & $\begin{array}{l}\text { PV195 (trpB3) } \\
\text { JV59 (trpE4) }\end{array}$ & $\begin{array}{l}\text { MLS } / \operatorname{Trp}^{+} 19 / 716(3) \\
\text { MLS }^{r} / \operatorname{Trp}^{+} 3 / 345(1)\end{array}$ & $\begin{array}{l}2 \cdot 7 \\
0.9\end{array}$ \\
\hline PV517 (spo-56) & PV195 & $\mathrm{MLS}^{\mathrm{r}} / \mathrm{Trp}^{+}$6/235 (2) & $2 \cdot 6$ \\
\hline PV518 (spo-57) & PV195 & $\mathrm{MLS}^{\mathrm{r}} / \mathrm{Trp}^{+} 4 / 304(2)$ & $1 \cdot 3$ \\
\hline PV519 (spo-58) & PV195 & $\mathrm{MLS}^{\mathrm{r}} / \mathrm{Trp}^{+} \quad 3 / 245(2)$ & $1 \cdot 2$ \\
\hline PV 503 (spo-54) & PV3 (hisH2l) & $\mathrm{MLS}^{\mathrm{r}} / \mathrm{His}^{+} \quad 2 / 99$ (1) & $2 \cdot 0$ \\
\hline PV497 (spo-54) & PV3 & $\mathrm{MLS}^{\mathrm{r}} / \mathrm{His}^{+} \quad$ 2/398 (2) & $0 \cdot 5$ \\
\hline PV517 (spo-56) & PV3 & $\mathrm{MLS}^{r} / \mathrm{His}^{+} \quad 5 / 237(2)$ & $2 \cdot 1$ \\
\hline PV518 (spo-57) & PV3 & $\mathrm{MLS}^{r} / \mathrm{His}^{+} \quad 0 / 262(2)$ & $<0.4$ \\
\hline PV519 (spo-58) & PV3 & $\mathrm{MLS}^{\mathrm{r}} / \mathrm{His}^{+}$1/210 (2) & 0.5 \\
\hline JV62 (trpE7) & JV109 (rib-2) & $\mathrm{Trp}^{-} / \mathrm{Rib}^{+} 22 / 805$ & $2 \cdot 7$ \\
\hline PV497 (spo-54) & JV109 & $\mathrm{MLS}^{\mathrm{r}} / \mathrm{Rib}^{+} \quad 0 / 704(2)$ & $<0 \cdot 1$ \\
\hline PV517 (spo-56) & JV109 & $\mathrm{MLS}^{\mathrm{r}} / \mathrm{Rib}^{+} 0 / 177(1)$ & $<0.6$ \\
\hline PV518 (spo-57) & JV109 & $\mathrm{MLS}^{\mathrm{r}} / \mathrm{Rib}^{+} \quad 0 / 189(1)$ & $<0.5$ \\
\hline PV519 (spo-58) & JV109 & $\mathrm{MLS}^{\mathrm{r}} / \mathrm{Rib}^{+}$0/177 (1) & $<0.6$ \\
\hline
\end{tabular}

* Cotransduction frequencies are reported as no. of unselected/no. of selected colonies. Numbers in parentheses denote the number of experiments.

plates. Since the plasmidless derivative of QM B1551 was blue on X-Gal plates, it was necessary to isolate a $\mathrm{Lac}^{-}$strain, which required a two-step mutagenesis. Whether both mutations were in the same gene is not known. Landman (1957) reported that wild-type $B$. megaterium, unlike $B$. subtilis, contains a $\beta$-galactosidase that is induced similarly to that of Escherichia coli, but is more unstable. By using the $\mathrm{Lac}^{-}$strain to isolate spo::lacZ-cat fusions, it was demonstrated that the transposon fusion method worked well in B. megaterium. The transposon not only facilitated the isolation of spo mutants, but also provided a simple way to study the kinetics of gene expression in the mutants by monitoring $\beta$-galactosidase activity. The fusion mutations were then transferred to a completely prototrophic background to test for the onset of gene expression in isogenic strains. The $100 \%$ cotransduction of MLS resistance with the $\mathrm{Spo}^{-}$phenotype and the correlation between the microscopically determined stage and the onset of expression of the lac $Z$ gene in spo-54 strongly suggests that the transposon was within, or very closely linked to the spo gene. By electron microscopy, spo-54 was shown to be either a spo0 or a spoI mutant since some cells were observed with slightly indented asymmetric septa. Yamamoto \& Balassa (1969) described a similar mutant, CA15, in B. subtilis. However, their mutant showed a mixture of cells with no septa, abortive septa (spikes) as well as completed septa. They designated it as an early 
spoII mutant. Chatelain \& Fargette (1976) briefly described a mutant of $B$. megaterium KM that is very similar to spo-54 and they designated it as a spoI mutant. SpoI mutants have not been isolated in $B$. subtilis, so the designation has been dropped. However, now at least two mutants have been isolated in two different backgrounds of B. megaterium (QM B1551 and KM) that seem to be blocked just before or at the start of septation. These mutants may be very useful in determining what gene product(s) is necessary for the initiation or elongation of asymmetric septation. Mutant spo-58, in contrast, was shown to complete septum formation and so is blocked at stage II. Mutants carrying spo-56 and spo58 fusions expressed the $\beta$-galactosidase at or just before $t_{0}$. The mutant carrying the $s p o-57$ fusion expressed the enzyme weakly, starting at $t_{1.5}-t_{2}$, and may be similar to spo-54. However, the electron microscopy and $\beta$ galactosidase assays have revealed that mutations in at least two genes have probably occurred among the four mutants characterized.

Various enzymes and compounds that are expressed at specific times during sporulation in B. subtilis (Waites et al., 1970) were tested in B. megaterium QM B1551 to establish the kinetics of expression in this strain and to determine whether they might be used to help distinguish mutants blocked at specific stages during our characterization of the fusion mutants. In $B$. subtilis, alkaline phosphatase is expressed at $t_{2}$, glucose dehydrogenase at $t_{3}$ and DPA between $t_{4}$ and $t_{5}$ (Waites et al., 1970). Production of alkaline phosphatase can be used to delineate some spoII mutants (Sandman et al., 1987) if care is taken to grow cells in the presence of a high phosphate concentration in order to inhibit the vegetative alkaline phosphatase produced at the beginning of stationary phase (Hulett \& Jensen, 1988). In SNB broth plus $5 \mathrm{mM}$-phosphate, $B$. megaterium wild-type did not begin to produce alkaline phosphatase until $t_{3}-t_{4}$, but all four mutants failed to produce this enzyme. Chatelain (1975) had previously reported production of alkaline phosphatase in $B$. megaterium strain $\mathrm{KM}$ at $\mathrm{t}_{0}$, but the experiment was done in medium containing no inorganic phosphate, so he may have measured the vegetative enzyme. Interestingly, he observed no enzyme activity even at $t_{6}$ in high phosphate. Our results suggest that alkaline phosphatase is produced $1-2 \mathrm{~h}$ later in $B$. megaterium than in $B$. subtilis and cannot be used to delineate earlier spo mutants. Glucose dehydrogenase, on the other hand, is produced in both species at about $t_{4}$. In agreement with our results, Chatelain (1975) also reported detection of glucose dehydrogenase between $t_{3}$ and $t_{5}$. DPA was detectable at $t_{5.5}$ in the whole cells used in this study, consistent with the results of Singh \& Setlow (1979), who could detect DPA in isolated forespores at about $t_{4}-t_{5}$, and La Nauze et al. (1974), who reported that DPA was produced during stage IV. The inability of the spo fusion mutants to produce alkaline phosphatase, glucose dehydrogenase or DPA confirmed that each mutant was blocked at a stage prior to their expression, i.e. before $t_{3}$.

Mutations in some spo0 genes in B. subtilis cause pleiotropic effects such as inhibition of production of antibiotic and proteases, and the development of motility and competency (Kawamura et al., 1985; Losick et al., 1986; Sandman et al., 1987). It was found during our study that both the mutant and wild-type strains of $B$. megaterium produced comparable levels of neutral protease. Millet \& Aubert (1969) reported that production of neutral protease in strain KM begins at the end of exponential growth in complex medium, but throughout vegetative growth in minimal medium. We also found that when grown in SNB, QM B1551 began to produce protease between $t_{0}$ and $t_{1}$, as has also been observed by Setlow (1974) for QM B1551. No correlation of protease production with sporulation was found by Chatelain (1975), Chatelain \& Fargette (1976) or Millet \& Aubert (1969) and no other extracellular protease has been reported for this species. The observation that all four spo mutants were protease positive was, therefore, consistent with previously reported results.

Other parameters considered were antibiotic production, competency and motility. No transformation competency has been detected in wild-type $B$. megaterium (P. S. Vary, unpublished data) and motility was poor, so these parameters could not be used to characterize mutants. Moreover, production of an antibiotic could not be demonstrated, although some strains of $B$. megaterium produce them. Either $B$. megaterium QM B1551 does not produce an antibiotic, or the early spo mutant strains we used were not sensitive to it. However, even wild-type $B$. megaterium was sensitive to the antibiotic produced by $B$. subtilis, while the antibiotic-sensitive $\operatorname{spo} 0 A$ mutant of $B$. subtilis exhibited no sensitivity to $B$. megaterium. However, these results do not completely rule out possible production of an antibiotic that does not affect B. subtilis.

Thus, we have shown that neutral protease production, competency or antibiotic production cannot be used to distinguish early sporulation mutants in $B$. megaterium. In contrast, glucose dehydrogenase and alkaline phosphatase production may in the future be useful in distinguishing some spoIII from spoIV mutants, and DPA production may differentiate some spoIV from spoV mutants. The production of these compounds during sporulation in QM B1551 permits the assay of new sporulation mutants.

Based upon the data presented, the fusion mutant spo54 has been tentatively designated as a spoI mutant, and the spo-58 mutant as spoII. Mutants spo-56 and spo-57 are 
expressed between $t_{0}$ and $t_{1}$ and may be spoI or spoII. The similarity of timing of the production of glucose dehydrogenase, DPA and intracellular refractile phasebright spores in B. megaterium and in B. subtilis also suggests that our designation of $\mathrm{t}_{0}$ is probably accurate to within $30 \mathrm{~min}$.

The mutant loci were mapped using a recently constructed $B$. megaterium mapping kit (Vary \& Tao, 1988), and were all found to be in the $\operatorname{trp}$-his $H$ region previously mapped by Callahan et al. (1983) and recently extended (Vary \& Tao, 1988; P. S. Vary \& S. L. Palm, unpublished). The four mutants isolated were all in the same region and were all early spo mutations. The twofactor crosses could not order the four mutations. Unfortunately, a marker to the 'right' of the spo genes close enough for cotransduction is not yet available. Why only early genes in the same region were isolated is not known. Possibilities are that there was a selection bias in the intensity of expression (deep-blue colonies) or perhaps there is a cluster of early spo genes near trp-his $H$ in $B$. megaterium. Indeed, the low frequency of sporulation mutants recovered $(15 \%)$ may also reflect a bias introduced by picking only deep-blue colonies since expression of early sporulation genes may have accumulated more of the 5-bromo-4-chloroindigo product of XGal. Alternatively, only genes with very strong promoters may have been selected and may be those in the trphis region. Much of the $\beta$-galactosidase production reported for $B$. subtilis sporulation genes has been low. It is fairly certain that mutations spoI54 and spoII58 are in different early genes based upon both the timing of gene expression and electron microscopy. All four mutations expressed at consistently different intensities (with spo58 exhibiting very strong expression) and at least $1-2 \mathrm{~h}$ apart. In $B$. subtilis, the spoOA locus is at $218^{\circ}$. There are two spoII mutations near the trp-his $H$ region, spoIIA and spoIIM at $211^{\circ}$ (Losick et al., 1986; Sandman et al., 1987). The spoIIA locus is expressed at about $t_{1}$ in $B$. subtilis and is composed of three genes (Errington \& Mandelstam, 1986). To our knowledge, the time of expression of spoIIM has not been reported. Since mapping of spo genes has just begun in B. megaterium, it is not known how the positions of spo genes on the chromosome will correlate with positions on $B$. subtilis. However, we have recently found that $s s p$ genes homologous to those in $B$. subtilis are more conserved in position than surrounding genes (Sussman et al., 1988). Whether that conservation of position will hold true with other spo genes should be of interest in understanding the evolution of the sporulation process in Bacillus.

In summary, the results demonstrate that the plasmid pTV53 carrying Tn917-lacZ-cat can be used as a fusion probe to identify spo mutants, map the spo loci and study the expression of their promoters in B. megaterium.
Moreover, the assay of several sporulation compounds and enzymes in both mutant and wild-type strains have helped establish parameters for the characterization of future spo mutants in this species.

We are grateful to James Vary for providing the JV mutants, and to Philip Youngman for providing pTV53 and his continued advice and support. We thank Dian Molsen for assistance in electron microscopy, and Freyja Altepeter for typing the manuscript.

This work was supported by grant DMB 8607259 from the National Science Foundation.

\section{References}

BACH, M. L. \& GilvarG, C. (1966). Biosynthesis of dipicolinic acid in sporulating Bacillus megaterium. Journal of Biological Chemistry 241, 4563-4566.

Bohall, N. A. \& VARY, P. S. (1986). Transposition of Tn917 in Bacillus megaterium. Journal of Bacteriology 167, 716-718.

BroNNER, F. \& Freund, T. S. (1972). Calcium accumulation during sporulation of Bacillus megaterium. In Spores V, pp. 187-190. Edited by H. O. Halvorson, R. Hanson \& L. L. Campbell. Washington, DC: American Society for Microbiology.

Callahan, J. P., Crawford, I. P., Hess, G. F. \& Vary, P. S. (1983). Cotransductional mapping of the trp-his region of Bacillus megaterium. Journal of Bacteriology 154, 1455-1458.

Chaloupka, J., Severin, A. I., Sastry, K. J., Kučerová, H. \& Strnadoví, M. (1982). Differences in the regulation of exocellular proteinase synthesis during growth and sporogenesis of Bacillus megaterium. Canadian Journal of Microbiology 28, 1214-1218.

Chatelain, S. (1975). Variations d'activities enzymatiques chez Bacillus megaterium dans differentes conditions de sporulation Comptes Rendus de l'Academie des Sciences, D 281, 1529-1532.

Chatelain, S. \& Fargette, F. (1976). Variations d'activities enzymatiques chez un mutant asporogène de Bacillus megaterium pour differentes carences nutrionelles. Comptes Rendus de l'Academie des Sciences, $D$ 283, 1563-1566.

Crafts-Lighty, A. \& Ellar, D. J. (1980). The structure of the outer membrane in dormant and germinated spores of Bacillus megaterium. Journal of Applied Bacteriology 48, 135-145.

Deutscher, M. P., Chambon, P. \& Kornberg, A. (1968). Biochemical studies of bacterial sporulation and germination. XI. Proteinsynthesizing systems from vegetative cells and spores of Bacillus megaterium. Journal of Biological Chemistry 243, 5117-5125.

Ellar, D. J. \& Posgate, J. A. (1974). Characterization of forespores isolated from Bacillus megaterium at different stages of development into mature spores. In Spore Research, pp. 21-40. Edited by A. N Barker, G. W. Gould \& J. Wolf. New York: Academic Press.

Ellar, D. J., Lundgren, D. G. \& Slepecky, R. A. (1967). Fine structure of Bacillus megaterium during synchronous growth. Journal of Bacteriology 94, 1189-1205.

Ellar, D. J., Eaton, M. W., Hogarth, C., Wilkinson, B. J., Deans, J. \& LA NAUZE, J. (1975). Comparative biochemistry and function of forespore and mother-cell compartments during sporulation of Bacillus megaterium cells. In Spores VI, pp. 425-433. Edited by P. Gerhardt, R. N. Costilow \& H. L. Sadoff. Washington, DC: American Society for Microbiology.

ENGLISH, J. D. \& VARY, P. S. (1986). Isolation of recombination defective and UV sensitive mutants of Bacillus megaterium. Journal of Bacteriology 165, 155-160.

ERrington, J. \& MANDELSTAM, J. (1986). Use of a lacZ gene fusion to determine the dependence pattern of sporulation operon spoIIA mutants of Bacillus subtilis. Journal of General Microbiology 132, 2967-2976

FLiss, E. R. \& SETLow, P. (1985). Genes for Bacillus megaterium small, acid-soluble spore proteins: nucleotide sequence of two genes and their expression during sporulation. Gene 35, 151-157.

Fliss, E. R., Connors, M. J., Loshon, C. A., Curiel-Quesada, E., Setlow, B. \& Setrow, P. (1985). Small, acid-soluble spore proteins 
of Bacillus: products of a sporulation-specific, multigene family. In Molecular Biology of Microbial Differentiation, pp. 60-66. Edited by J. Hoch \& P. Setlow. Washington, DC: American Society for Microbiology.

Greene, R. A., Holt, S. C., Leadbetter, E. R. \& Slepecky, R. A. (1971). Correlation of light and electron microscopic observations of sporulation in Bacillus megaterium. In Spore Research, pp. 161-180. Edited by A. N. Barker, G. W. Gould \& J. Wolf. London: Academic Press.

HILL, S. H. A. (1983). spoVH and spoVJ - new sporulation loci in Bacillus subtilis 168. Journal of General Microbiology 129, 293-302.

HIRSCH, J. G. \& FEDORKO, M. F. (1968). Ultrastructure of human leukocytes after simultaneous fixation with glutaraldehyde and osmium tetroxide and 'post-fixation' in uranyl acetate. Journal of Cell Biology 38, 615-627.

Hogarth, C. \& Ellar D. J. (1978). Calcium accumulation during sporulation of Bacillus megaterium KM. Biochemical Journal 176 197-203.

HUlett, F. M. \& JENSEN, K. (1988). Critical roles of $s p o 0 A$ and $s p o 0 H$ in vegetative alkaline phosphatase production in Bacillus subtilis. Journal of Bacteriology 170, 3765-3768.

Imagawa, M., OKu, Y., El-Belbasi, H. I., Teroaka, M., Nishihara, T. \& KonDO, M. (1985). Synthesis and deposition of spore coat proteins during sporulation of Bacillus megaterium. Microbiology and Immunology 29, 1151-1162.

JanOFF, A. S., Coughlin, R. T., Racine, F. M., McGroarty, E. J. \& VARY, J. C. (1979). Use of electron spin resonance to study Bacillus megaterium spore membranes. Biochemical and Biophysical Research Communications 89, 565-570

JANSSEN, F. W., Lund, A. J. \& ANDERson, L. E. (1958). Colorimetric assay for dipicolinic acid in bacterial spores. Science 127, 26-27.

KaWamura, F., Wang, L.-F. \& DoI, R. H. (1985). Catabolite-resistant sporulation (crsA) mutations in the Bacillus subtilis RNA polymerase $\sigma^{43}$ gene (rpoD) can suppress and be suppressed by mutations in spoO genes. Proceedings of the National Academy of Sciences of the United States of America 82, 8124-8128.

KEMPER, J. (1974). Gene order and cotransduction in the leu-ara-folpyrA region of the Salmonella typhimurium linkage map. Journal of Bacteriology 117, 94-97.

Koshikawa, T., Beaman, T. C., Pankratz, H. S., Nakashio, S., CoRner, T. R. \& Gerhardt, P. (1984). Resistance, germination, and permeability correlates of Bacillus megaterium spores successfully divested of integument layers. Journal of Bacteriology 159, 624632.

KRETSCHMER, S. \& FIELdeR, G. (1974). Septation sporogener und asporogener Bacillus megaterium-Zellen während des Übergangs zu Stickstoff- und Kohlenstoff-hunger. Zeitschrift für Allgemeine Mikrobiologie 14, 303-312.

la Nauze, J. M., Ellar, D. J., Denton, G. \& Posgate, J. A. (1974). Some properties of forespores isolated from Bacillus megaterium. In Spore Research, pp. 41-46. Edited by A. N. Barker, G. W. Gould \& J. Wolf. New York: Academic Press.

Landman, O. E. (1957). Properties and induction of $\beta$-galactosidase in Bacillus megaterium. Biochimica et Biophysica Acta 23, 558-569.

LEVINE, M. (1957). Mutations in the temperate phage P22 and lysogeny in Salmonella. Virology 3, 22-41.

Losick, R., Youngman, P. \& Piggot, P. J. (1986). Genetics of endospore formation in Bacillus subtilis. Annual Review of Genetics 20 , 625-669.

Mandelstam, J. \& Errington, J. (1987). Dependent sequences of gene expression controlling spore formation in Bacillus subtilis. Microbiological Sciences 4, 238-244.

Miller, J. H. (1972). Experiments in Molecular Genetics, pp. 352-355. Cold Spring Harbor, New York: Cold Spring Harbor Laboratory.

Millet, J. \& AUberT, J.-P. (1969). Étude de la megateriopeptidase, protease exocellulaire de Bacillus megaterium. III. Biosynthèse et rôle physiologique. Annales de I'Institut Pasteur 117, 461-473.

OTA, A. (1980). Calcium uptake by Bacillus megaterium mutant strains unable to sporulate. International Journal of Biochemistry 11, 363-367.

PigGot, P. J. \& Hoch, J. A. (1985). Revised genetic linkage map of Bacillus subtilis. Microbiological Reviews 49, 158-179.

Priest, F. G. (1977). Extracellular enzyme synthesis in the genus Bacillus. Bacteriological Reviews 41, 711-753.
Rotman, Y. \& Fields, M. L. (1968). A modified reagent for dipicolinic acid analysis. Analytical Biochemistry 22, 168-172.

Sadoff, H. L., BaCh, J. A. \& Kools, J. W. (1965). Significance of multiple forms of glucose dehydrogenase in relation to its heat resistance. In Spores III, pp. 97-109. Edited by L. L. Campbell \& H. O. Halvorson. Ann Arbor, Michigan: American Society for Microbiology.

Sandman, K., Losick, R. \& Youngman, P. (1987). Genetic analysis of Bacillus subtilis spo mutations generated by Tn 917 -mediated insertional mutagenesis. Genetics 117, 603-617.

SCANDella, C. J. \& Kornberg, A. (1969). Biochemical studies of bacterial sporulation and germination. XV. Fatty acids in growth, sporulation and germination of Bacillus megaterium. Journal of Bacteriology 98, 82-86.

SETLOW, P. (1974). Polyamine levels during growth, sporulation, and spore germination of Bacillus megaterium. Journal of Bacteriology 117, 1171-1177.

SETLOw, P. (1975). Protease and peptidase activities in growing and sporulating cells and dormant spores of Bacillus megaterium. Journal of Bacteriology 122, 642-649.

SinGH, R. P. \& SETLOw, P. (1979). Regulation of phosphoglycerate phosphomutase in developing forespores and dormant and germinated spores of Bacillus megaterium by the level of free manganous ions. Journal of Bacteriology 139, 889-898.

Sussman, M. D., Vary, P. S., Hartman, C. \& Setlow, P. (1988). Integration and mapping of Bacillus megaterium genes which code for small, acid soluble spore proteins and their protease. Journal of Bacteriology 170, 4942-4945.

Szulmajster, J. \& Hanson, R. (1965). Physiological control of sporulation in Bacillus subtilis. In Spores III, pp. 162-173. Edited by L. L. Campbell \& H. O. Halvorson. Ann Arbor, Michigan: American Society for Microbiology.

ToDD, J. A. \& Ellar, D. J. (1982). Alteration in the penicillin-binding profile of Bacillus megaterium during sporulation. Nature, London 300, 640-643.

Tomich, P. K., AN, F. Y. \& Clewell, D. B. (1980). Properties of erythromycin- inducible transposon Tn917 in Streptococcus faecalis. Journal of Bacteriology 141, 1366-1374.

VARY, P. S. (1979). Transduction in Bacillus megaterium. Biochemical and Biophysical Research Communications 88, 1119-1124.

VARY, P. S. \& TAO, Y.-P. (1988). Development of genetic methods in Bacillus megaterium. In Genetics and Biotechnology of Bacilli, vol. 2, pp. 403-407. Edited by A. T. Ganesan \& J. A. Hoch. New York: Academic Press.

VON TERSCH, M. A. \& CaRLton, B. C. (1983). Megacinogenic plasmids of Bacillus megaterium. Journal of Bacteriology 155, 872-877.

WaITES, W. M., KaY, D., DaWES, I. W., WoOD, D. A., Warren, S. C. \& Mandelstam, J. (1970). Sporulation in Bacillus subtilis. Correlation of biochemical events with morphological changes in asporogenous mutants. Biochemical Journal 118, 667-676.

Wilkinson, B. J. \& EllaR, D. J. (1975). Morphogenesis of the membrane bound electron-transport system in sporulating Bacillus megaterium KM. European Journal of Biochemistry 55, 131-139.

YAMAMOTO, T. \& BALASSA, G. (1969). Biochemical genetics of bacterial sporulation. II. Membrane development during sporulation of $B$. subtilis and its mutants. Molecular and General Genetics 106, 1-13.

Youngman, P., Perkins, J. B. \& Sandman, K. (1985a). Use of Tn917mediated transcriptional gene fusions to lac $Z$ and $c a t-86$ for the identification and study of spo genes in Bacillus subtilis. In Molecular Biology of Microbial Differentiation, pp. 47-54. Edited by J. A. Hoch \& P. Setlow. Washington, DC: American Society for Microbiology. Youngman, P., Zuber, P., Perkins, J. B., Sandman, K., Igo, M. \& Losick, R. (1985b). New ways to study developmental genes in spore-forming bacteria. Science 228, 285-291.

Youngman, P., Poth, H., Green, B., York, K., Olmede, G. \& Smith, K. (1989). Methods for genetic manipulation, cloning and functional analysis of sporulation genes in Bacillus subtilis. In Regulation of Prokaryotes Development, Structural and Functional Analysis of Bacterial Sporulation and Germination, pp. 65-88. Edited by I. Smith, R. A. Slepecky \& P. Setlow. Washington, DC: American Society for Microbiology. 